\title{
Assessment of Blue and Green Virtual Water Trade: A Case Study of India
}

\author{
Shiv Narayan Nishad and Naresh Kumar
}

\section{ABSTRACT}

\begin{abstract}
Declining water resources and increasing demand of water for agricultural, industrial, and domestic sector and potential climate change has posed a major challenge to maintain water sustainability of a nation. There is a need to adopt long-term perspective for assessment and policy design for sustainability of primary resources like water. It is also argued that virtual water trade has raised issues of water sustainability as even small but continuous net virtual water trade may influence the water sustainability through irreversible losses. With the constraints for water sustainability, virtual water trade has received much attention in the recent years. While the impact of virtual water trade on water sustainability of virtual water exporter country is less explored and assessed. India is a major water exporting country resulted tremendous pressure on water resources that has serious threat to food security and the negative impact on development of economy and other sectors.
\end{abstract}

Keywords: food sustainability, Net Virtual water export, Virtual water export/import, Virtual water trade, Water footprint, Water sustainability.
Submitted : July 01, 2021

Published : November 15, 2021

ISSN: $2684-1827$

DOI: 10.24018 /ejfood.2021.3.6.336

Shiv Narayan Nishad*

National Institute of Science Communication and Policy Research, Delhi, India.

(e-mail: s.nishad@nistads.res.in)

Naresh Kumar

National Institute of Science

Communication and Policy Research, Delhi, India.

(e-mail: nareshkr@nistads.res.in)

*Corresponding Author

\section{INTRODUCTION}

Worldwide increasing trend in economies and growth of population has raised the demand of fresh water resulted increasing trend in occurrence of water shortage more frequently than ever before [1]-[7]. It was estimated about 4 billion population facing severe water scarcity for at least one month of the year, while the water demand exceeds the availability of water for utilization [8]. In the developing world, more than one billion people do not have access to sufficient water for drinking. Due to highly consumption of water resources for agricultural production for feeding the growing population, many countries are facing serious water scarcity [9]-[12]. About $80 \%$ of the available water is used for agricultural purposes and is particularly vulnerable for water scarcity. The primary resources like water are comparatively fixed and even declining across the world while water demand for different sectors continue to increase [5], [13]. There are multiple stresses on surface and groundwater resources from natural to anthropogenic activities. In addition, there are several studies have shown potential impact of climate change on water resource and thus on food security [14]-[17]. So, there is urgent need of water saving methodology in those countries of experiencing water stress and water scarcity and have potential impact of climate change that will cause further stress on water resources and variation in water availability. Changes in water availability might affect the availability of food and thus affects food sustainability of the country [13], [18], [19]. With such emerging issues, virtual water trade has gained attention in the recent year for better management and sustainability of water resource [20]-[26].
The virtual water trade was coined for the water scarce countries to save their water resources by importing water intensive crops to meet the food demand [22], [23], [27]. It has become the medium for sharing fresh water resources and globalization of water resources through trade networks [28][35]. In addition, virtual water trade is one of the alternatives that can provide a more integrated approach for better water management and water use efficiency for water scarce country [36]-[40]. With several benefits of virtual water trade, there are some drawbacks like excessive virtual water trade can help to increase the economy but also it can have implications on country's water resource and may increase the water scarcity [18], [41]-[43]. Several studies have shown the implications of net virtual water export on water sustainability of a nation.

The concept of virtual water helps to understand the water consumption to produce different goods and services. This understanding and the knowledge can help to the best use of scarce water resource to produce the goods and services especially in the water scarce regions, semi-arid and arid areas. Water footprint of the agricultural, the volume of freshwater used to produce the agricultural product, depends on geographical location, time and the water use efficiency, which helps to establish the relation between consumption patterns and water use and indicates the environment impact of consuming the product [44]-[47]. This concept was introduced as an attempt to understand how international trade affects the global flow of water. Water footprint is classified in three water footprint: green water footprint, blue water footprint and grey water footprint [46]. Green water footprint and blue water footprint represent the source of water utilized for production of the crop; green water 
footprint represents the amount of water used to production of the crop from rainfall while the blue water footprint represents the water used from surface water and ground water.

Agricultural is the major sector of India that provides employment to more about than $42 \%$ of the population and plays an important role in national and international food security. In addition, agricultural is the major water intensive sector that consumes about $80 \%$ of total water resources for production of the crops. Increasing population and changing consumption is leading to increase demand for food and thus dependency on water will increase. In addition, several studies have highlighted the negative impact of changing climate on water resources for India. Currently, India's per capita water availability has become less than standard water requirement for one person $\left(1700 \mathrm{~m}^{3}\right.$ per capita per year). Along with these, there are rapidly declining trend in ground water in major food producing states like Punjab, Haryana, Uttar Pradesh, Tamil Nadu, and Karnataka [48]. Most of the Indian regions are at very high risks in many states and about 600 million people face high to extreme water stress and about $75 \%$ of households do not have access to clean drinking water on their house [48]. India is facing high water scarcity. While having only $4 \%$ of world's fresh water resources, India needs to meet the demand of more than 1300 million population; about $16 \%$ of total world's Population. The average precipitation is about 4000 billion $\mathrm{m}^{3}$. The total natural runoff is about 1869 billion $\mathrm{m}^{3}$, while utilizable water is 1123 billion $\mathrm{m}^{3}$ (690 billion $\mathrm{m}^{3}$ surface water and 433 billion $\mathrm{m}^{3}$ ground water). Only $28 \%$ of total water is utilizable for different sectors [48].

In addition, India has become major virtual water exporter country exporting water embedding in the agricultural products while the water saving through virtual water import is negligible from 1990s. Therefore, there is urgent need of virtual water trade policy to balance the water resources. Several approaches and frameworks are available for the assessment of virtual water trade, there is less explored of long-term effects of virtual water export on water resource. A quantitative analysis of virtual water trade combining with constraints like declining water resource can provide significant insights into the dynamics of water sustainability and implications and needs special attention. There is a need to analyze the virtual water trade and inputs to the policymakers for better management of water resources. The main objective of this study is the analysis of dynamics of virtual water trade and its effects on loss of water sustainability. The study provides virtual water trade in terms of green water and blue water footprint to explore the dependency of sources. The study also estimates the net virtual water export of food grains and all crops in terms of green water and blue water footprint. We have considered food grains and other crops like pulses, vegetables, fruit, oil crops and roots crops for the presents study and excluded sugarcane, jute, and fibre crops.

\section{FORMULATION}

\section{A. Water Demand for Agricultural Production}

Water demand for the production of crops is the multiplication of total production of the crop and the water required to produce the crop $\mathrm{m}^{3}$ per ton, which depends on the type of the crop. The total water required for production of the crop is defined as:

$$
\begin{aligned}
& W_{P}(t)=\sum_{i=1}^{N_{C p}} F_{P}(i, t) * W_{F P}(i) \\
& \text { Here } F_{P}(i, t)=A_{P}(i, t) * A_{G}(i, t) \\
& W_{F P}(i)=W_{G F P}(i)+W_{B F P}(i)
\end{aligned}
$$

Here $F_{P}(i, t)$ represents the production of the $\mathrm{i}^{\text {th }}$ crop in the year $t$ and $W_{F P}(i)$ represents the total water footprint of the $\mathrm{i}^{\text {th }}$ crop, which is sum of the green water footprint $\left(W_{G F P}(i)\right)$ and blue water footprint $\left(W_{B F P}(i)\right)$ of the crop $i$. $W_{P}(t)$ represents the total water required to produce all the crops[18]. $N_{C P}$ represents the number of crops. $A_{P}(i, t)$ and $A_{G}(i, t)$, respectively, represent the agricultural productivity and harvested area of the $i^{\text {th }}$ crop in the year $t$.

\section{B. Virtual Water Export}

The virtual water export is calculated in terms of green water footprint and blue water footprint which is defined as:

$$
\begin{aligned}
& W_{E P G}(t)=\sum_{i=1}^{N_{C P}} F_{E}(i, t) * W_{G F P}(i) \\
& W_{E P B}(t)=\sum_{i=1}^{N_{C P}} F_{E}(i, t) * W_{B F P}(i)
\end{aligned}
$$

Here $W_{E P G}(t)$ and $W_{E P B}(t)$ represent the green virtual water export and blue virtual water export in the year $t$.

Total virtual water export is defined as:

$$
W_{E P}(t)=\sum_{i=1}^{N_{C P}} F_{E}(i, t) * W_{F P}(i)
$$

Here $W_{E P}(t)$ represents the total virtual water export in the year $\mathrm{t}$.

\section{Virtual Water Import}

The virtual water import is calculated in terms of green water footprint and blue water footprint which is defined as

$$
\begin{aligned}
& W_{I P G}(t)=\sum_{j=1}^{N_{C}} \sum_{i=1}^{N_{C P}} F_{I}(i, j, t) * W_{G F P}(\mathrm{i}, \mathrm{j}) \\
& W_{I P B}(t)=\sum_{j=1}^{N_{C}} \sum_{i=1}^{N_{C P}} F_{I}(i, j, t) * W_{B F P}(\mathrm{i}, \mathrm{j})
\end{aligned}
$$

Here $W_{I P G}(t)$ and $W_{I P B}(t)$ represent the green virtual water export and blue virtual water import in the year $\mathrm{t}$.

The total virtual water import is calculated as:

$W_{I P}(t)=\sum_{j=1}^{N_{C}} \sum_{i=1}^{N_{C P}} F_{I}(i, j, t) * W_{F P}(\mathrm{i}, \mathrm{j})$

Here $W_{I P}(t)$ represents the total virtual water import in terms of total water footprint of the ith crops of jth country. Here, $W_{F P}(i, j)$ represents the water footprint the of $\mathrm{i}^{\text {th }}$ crop imported from $j^{\text {th }}$ country to India. Here we have considered global average water footprint of the crop that imported from other countries. $N_{C}$ represents the number of countries imports the agricultural products to India. 


\section{Virtual Water Net Export (Trade Balance)}

Net Virtual water export in terms of green water footprint and blue water footprint is calculated as:

$W_{N V E G}(t)=W_{E P G}(t)-W_{I P G}(t)$

$W_{N V E B}(t)=W_{E P B}(t)-W_{I P B}(t)$

The net virtual water export is calculated as:

$W_{T B P}(t)=W_{E P}(t)-W_{I P}(t)$

Here $W_{T B P}(t)$ represents the net virtual water exports in terms of water required for production of food grains and all crops in the year $\mathrm{t}$.

\section{E. Methods}

The international trade pattern (export/import) of agricultural products is adopted from the database available in public domain like FAOSTAT [49]. Agricultural production, food consumption and food supply are also adopted from the database FAOSTAT. While the databases of water resources like surface water, ground water, total renewable water resources and the per capita water available is adopted from the database AQUASTAT [50] available in public domain and Central water Commission reports published by Ministry of Jal Shakti, Govt. of India [51]. These data were collected from the year 1960 to 2018. The green water footprint and blue water footprint of the crops is adopted Mekonnen and Hoekstra [46]. The total water footprint of a crop is considered here as sum of green and blue water footprint. The green water footprint represents the amount of water used to produce 1 ton of the crop. While the blue water footprint represents the amount of fresh water used to produce 1 ton of the crop. Similarly, grey water footprint represents the amount of water required to dilute the pollutants to produce the 1 ton of the crop, which is not considered in the presents study due to not usage for production. In the presents study, we have considered only blue and green water footprint. In the presents study, we have considered all food crops like food grains, pulses, fruits, vegetables, roots \& tubers, sugarcane, and oil crops only; we have not considered agricultural derived products and nonfood items crops like jutes and fiber crops in this study.

\section{RESULTS}

\section{A. Global per Capita Water Availability}

For sustainable survival of humans, environment and the whole ecosystem, there is water scarcity for domestic, agriculture and industrial sector. Global and regional analysis of per capita water availability shows that Asian and African countries including India are facing water scarcity problem. The per capita water availability of India is less than $1700 \mathrm{~m}^{3}$ per capita; standard per capita water requirement for survival of a person (Fig. 1, top panel). There is declining trend worldwide in per capita water availability (Fig. 1, Bottom panel). The trend analysis of per capita water availability shows a large variation across the world. There is major declining trend in the South American Countries, China,
Australia, and African countries which is in the range -4000 to -500 . The declining trend of per capita water availability of the USA is also in the range -500 to -100 while India's trend is -50 to 0 . Only Russia is the country which has positive trend in per capita water availability (Fig. 1, bottom panel).

\section{Per capita Water availbility(Cubic Meter) (2013-2017)}

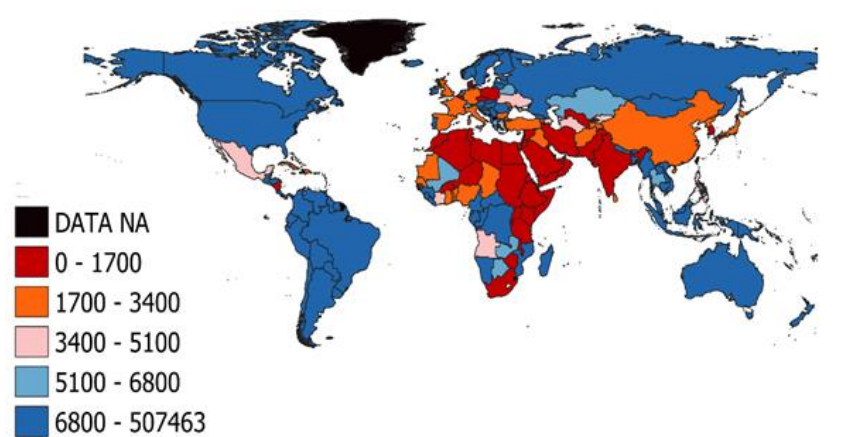

Linear Trend (1952-2017)

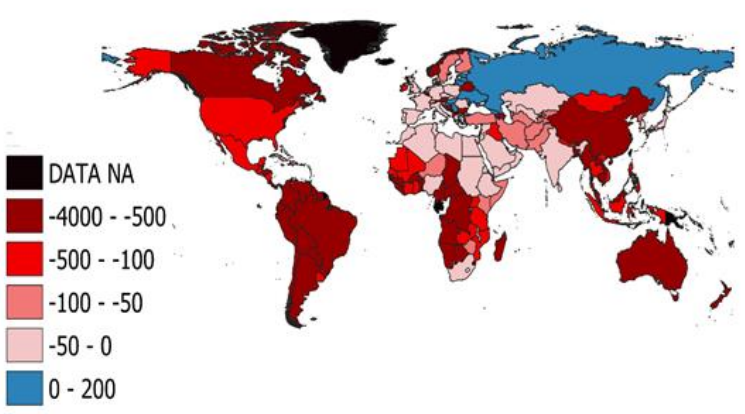

Fig. 1. Global analysis of per capita water availability and linear trend in per capita water availability. The data is adopted from AQUASTAT for the period 1952 to 2017 . The above map is symbolic used for analysis.

\section{B. Water Demand for Production of Food Grains and All Crops for India}

The water demand of all crops and food grains has been calculated in terms of green water footprint, blue water footprint and total water footprint. The water demand for production of food grains, in terms of green water footprint, has increased threefold from the year 1961 to 2018; increased from 169 billion $\mathrm{m}^{3}$ to 438 billion $\mathrm{m}^{3}$, while the water demand for food grains is about $23 \%$ of total water available. Similarly, results have shown for the blue water demand for production of food grains; blue water demand has increased from 40 billion $\mathrm{m}^{3}$ to 212 billion $\mathrm{m}^{3}$ in the period 1961-2018. In terms of percentage of total water available, the blue water demand for production of food grain is $10 \%$ of total water available. While total water demand for production of food grains is 639 billion $\mathrm{m}^{3}$ equivalent to $33 \%$ of total water available in the year 2018 (Fig. 2).

For production of all crops, the green water, blue water, and total water demand, respectively, are 958 billion $\mathrm{m}^{3}, 290$ billion $\mathrm{m}^{3}$ and 1248 billion $\mathrm{m}^{3}$ in the year 2018. While the green water, blue water, and total water demand, respectively, are 301 billion $\mathrm{m}^{3}, 58$ billion $\mathrm{m}^{3}$ and 359 billion $\mathrm{m}^{3}$ in the year 1961. In terms of percentage, the green water demand for production of all crops is $50 \%$ of the total water available; the blue water and total water demand is $15 \%$ and $65 \%$ of total available (Fig. 2). 

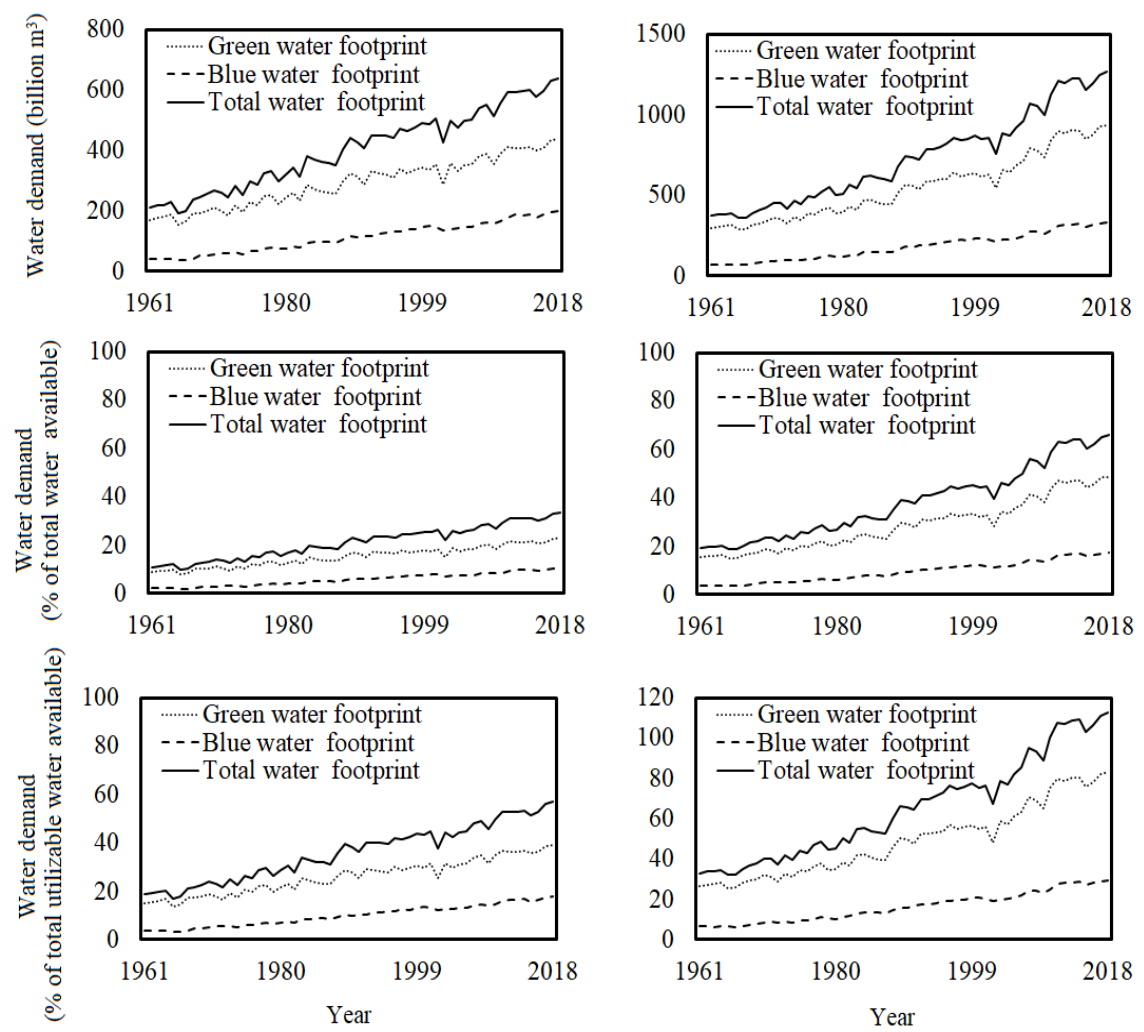

Fig. 2. The total water demand in terms Green water footprint (dotted line), blue water footprint (dash line) and total water footprint (solid line) is given in quantity billion $\mathrm{m}^{3}(\mathrm{BCM})$ (top panel) and percentage of total water available (bottom panel) for production of food grains (left panels) and all crops (right panels).

TABLE I: GReEN WATER, BLUe WATER AND TOTAL WATER REQUiRed FOR PRODUCTION OF CROPS

\begin{tabular}{|c|c|c|c|c|c|c|}
\hline \multirow{2}{*}{ Crops } & \multicolumn{3}{|c|}{$\begin{array}{l}\text { Water required for production } \\
\left(\text { billion } \mathrm{m}^{3}\right)\end{array}$} & \multicolumn{3}{|c|}{$\begin{array}{c}\text { Water required for production } \\
\text { (\% of total water available) }\end{array}$} \\
\hline & $\begin{array}{l}\text { Green water } \\
\text { required }\end{array}$ & $\begin{array}{c}\text { Blue water } \\
\text { required }\end{array}$ & $\begin{array}{c}\text { Total water } \\
\text { required }\end{array}$ & $\begin{array}{l}\text { Green water } \\
\text { required }\end{array}$ & $\begin{array}{c}\text { Blue water } \\
\text { required }\end{array}$ & $\begin{array}{c}\text { Total water } \\
\text { required }\end{array}$ \\
\hline Food grains & 439 & 200 & 639 & 23 & 10 & 33 \\
\hline Fruits & 70 & 25 & 94 & 4 & 1 & 5 \\
\hline Vegetables & 22 & 8 & 30 & 1 & 0 & 2 \\
\hline Pulses & 132 & 3 & 135 & 7 & 0 & 7 \\
\hline Oil crops & 241 & 45 & 285 & 13 & 2 & 15 \\
\hline Starchy Root \& Tubers & 56 & 9 & 65 & 3 & 0 & 3 \\
\hline All Crops & 959 & 290 & 1248 & 50 & 15 & 65 \\
\hline
\end{tabular}

The comparative analysis of green water, blue water and total required for production of food grains and all crops is given in Table I. The comparative analysis of water foot all crops group shows that the green water footprint and blue water footprint for the food grains are higher than other groups of crops. The green water required for production is also higher than blue water requirement for the production of all crops (Table I).

\section{Virtual Water Export and Virtual Water Import}

In the presents study, we have calculated the virtual water export and virtual water import in terms of green water footprint, blue water footprint and total water footprint (sum of blue and green water footprint) for India from the year 1961 to 2018 for food grains and all crops. The total virtual water export was negligible until 1990s and then it turned positive onwards. The total virtual water export of food grains and all crops, respectively, are 40 billion $\mathrm{m}^{3}$ and 60 billion $\mathrm{m}^{3}$ in the year 2018. While the green water export for food grains and all crops, respectively, are 30 billion $\mathrm{m}^{3}$ and 40 billion $\mathrm{m}^{3}$ in the year 2018. Similarly, the blue water footprint for food grains and all crops are approximately same 15 billion $\mathrm{m}^{3}$
(Fig. 3).

In contrast, virtual water import was higher in the early 1960s and then became negligible for food grains from 1990 onwards. Similar trends have also shown for all crops. The water saving through virtual water import is zero from 1990s while the water loss through virtual water export is higher in the 2018 resulted India has become the major water exporter in the world (Fig. 3). He virtual water exports is considered as water loss that is irreversible and going to other countries.

In terms of total water available, the virtual water export has increasing trend, which is about $2 \%$ of total water available exported through the export of food commodities of food grains and all crops (Fig. 4). Food grains are major exported crops in India while other crops are exported in very less quantity. In terms of water footprint, the volume of green virtual water export is higher than blue virtual water export in the total virtual water export (Fig. 4). Virtual water export was negligible until 1990, there is increasing trend onwards.

The virtual water export, in terms of utilizable water (1123 billion $\mathrm{m}^{3}$ ), the total virtual water export is about $5 \%$, while the contribution of green water and blue water, respectively, are $4 \%$ and $1 \%$ (Fig. 4 ). 

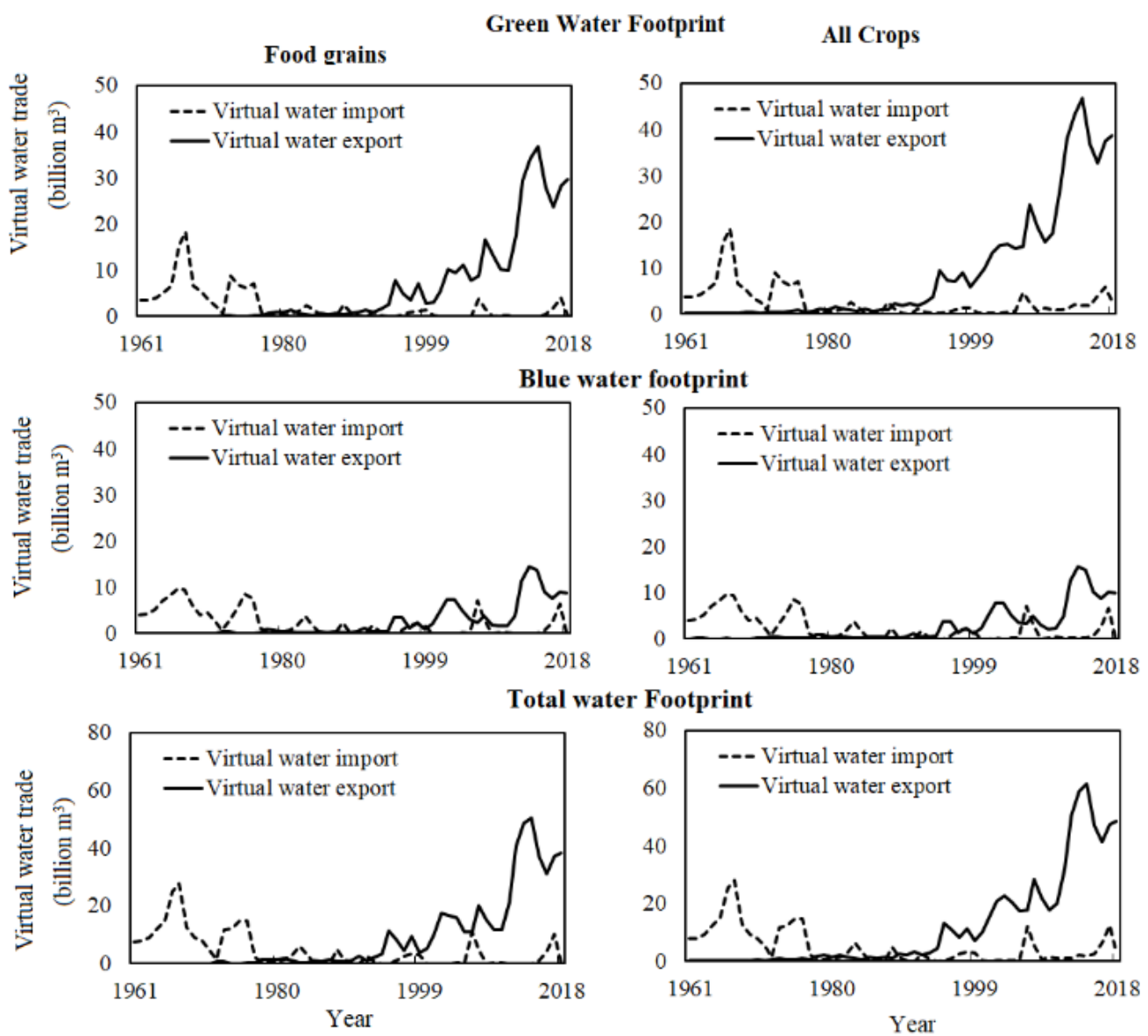

Fig. 3. Virtual water export (filled) and virtual water import (white filled) in terms of green water footprint (top panel), blue water footprint (middle panel) and total water footprint (bottom panel) for food grains and all crops.

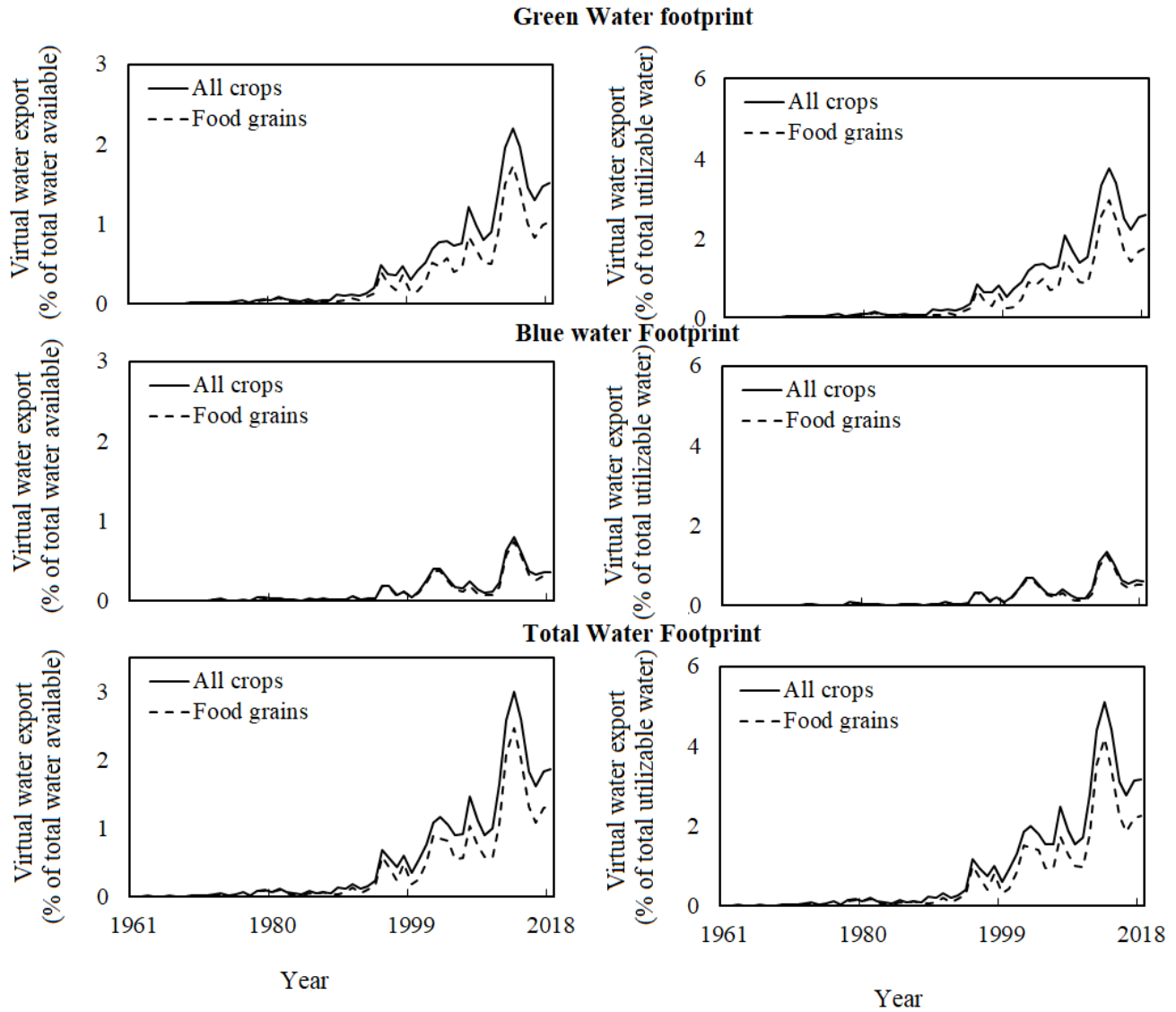

Fig. 4. Virtual water export as percentage of total water available (left panels) and percentage of total utilizable water (right panels) of in terms of green, blue, and total water footprint of all crops (solid line) and food grains (dash line) for the period 1961 to 2018. 


\section{Net Virtual Water Trade}

The net virtual water trade has given in terms of green water, blue water, and total virtual water footprint. The net virtual water exports were negative until 1990 afterwards it has turned positive and became major virtual water exporter of all crops and food grains. In terms of green water, the net virtual water 20 billion $\mathrm{m}^{3}$ in 2018 while it was negative in the period 1961 to 1990 (Fig. 5). Similarly, the net virtual exports in terms of blue water are about 10 billion $\mathrm{m}^{3}$ which is irreversible. The net virtual water export is about $2.5 \%$ of total water available while the net blue virtual water export is less than $1 \%$ of total water availability (Fig. 5).

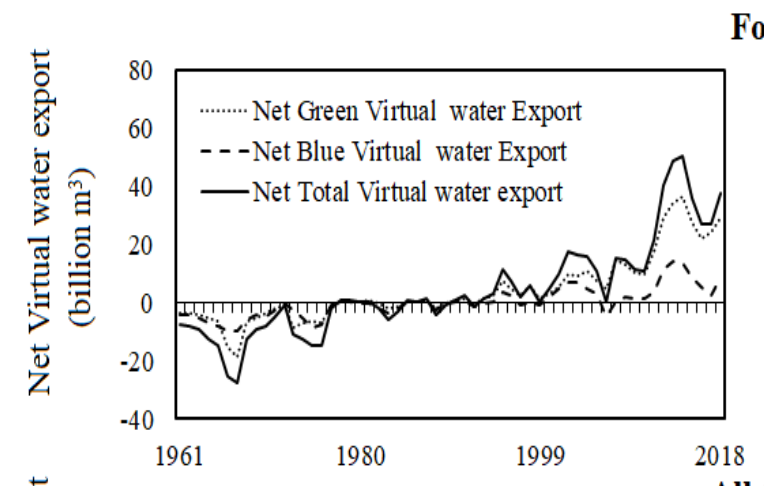

Food grains
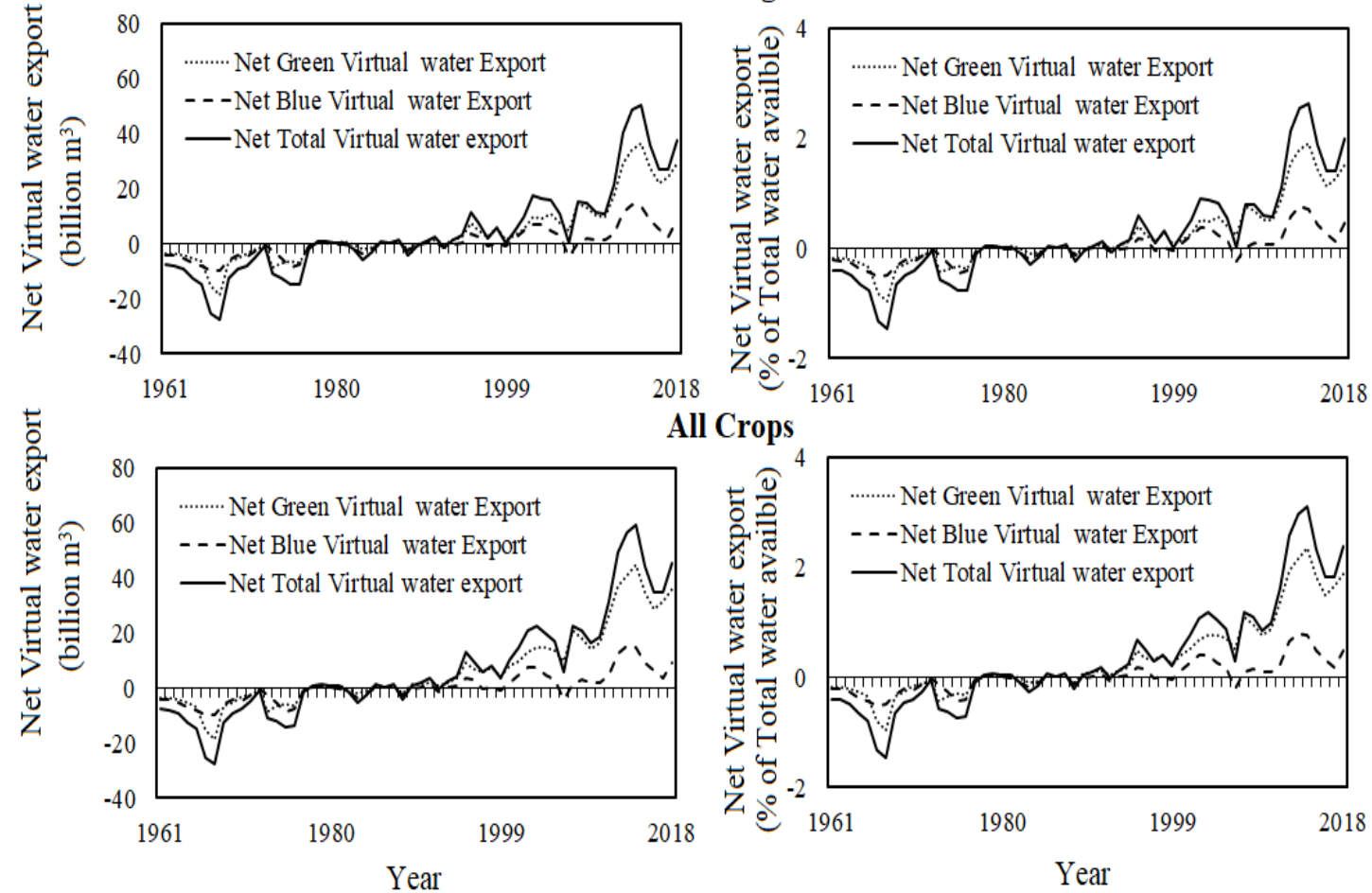

All Crops

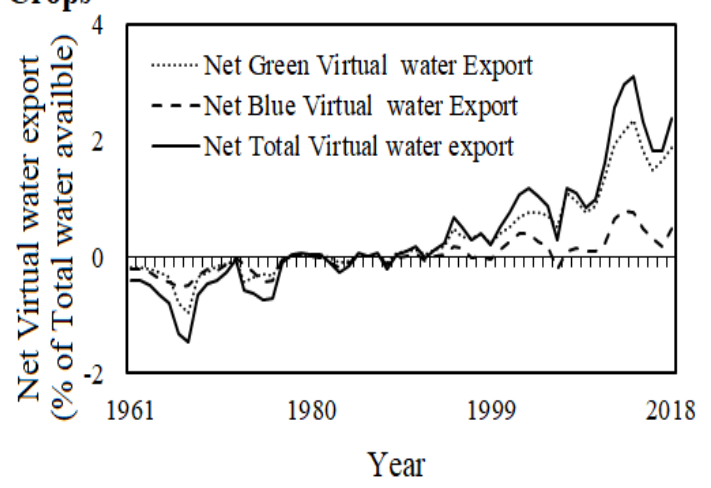

Fig. 5. Net virtual water export in terms of green water footprint (dotted line), blue water footprint (dash line) and total water footprint (solid line) in terms of quantity (left panels) and in percentage of total water available (right panels) food grains (top panel) and all crops (bottom panel).

\section{CONCLUSION}

Food security and food sustainability, basically, depend on primary resources like arable land and water, any changes may pose the significant impact on the sustainable availability of agricultural products. The arable land is fixed, while the other primary resource water can be transported across the globe through virtual water export or virtual water import. The virtual water export/import is accompanied with the agricultural products that is exported. Our analysis shows that the magnitude of net virtual water export can affect the water sustainability that can lead to the loss of water sustainability in irreversible manner. According to the Water Footprint Network (WFN) database, India had the lowest virtual imports of water in the world and a large virtual net export of water because of agricultural products. So, while the country strives to increase manufacturing exports, care should be taken to maximize water use efficiency lest it ends up virtually exporting more water.

The present analysis shows that the dependency on the green water and blue water for agricultural production. The results shows that the Indian agriculture primarily dependent on green water and some crops like wheat are dependent on blue water. Shrinking of rainfall, declining trend in rainfall, changing rainfall pattern with potential climate change may reduce the water availability for agricultural production that will affect the overall food sustainability. The water footprint of all crops and food grains, respectively, has reached about $70 \%$ and $40 \%$ of total water available, respectively. Dependency on blue water has become double in the recent years which shows improvement in the irrigation facility in India. On the other hand, there are some regions which are over extracted the ground water for irrigation resulted become a critical region. There is need of sustainable policy for using ground water and surface water for irrigation in India [52]. There are several constrains which affects the availability of green water and blue water. In addition, increasing economies, population growth and changing climate may become major constraints for achieving sustainability in water. Any significant change in availability of green water or blue water may have large impact on water sustainability and thus food sustainability.

Along with these constrains, virtual water export is also becoming major factor for loss of water sustainability of the water scarce region. Our analysis shows that India has become the major virtual water exporter in terms export of food grains across the world. Such magnitude of virtual water trade may affect the water sustainability in irreversible manner. The net virtual water export kept negative until 1990s and turn positive and increases manifold in recently. The total virtual water export has become about 60 billion $\mathrm{m}^{3}$ ( $3.1 \%$ of total water available). The net virtual water export is about 40 billion $\mathrm{m}^{3}$ (about $2 \%$ of total water available). On the other hand, the water saving through virtual water import 
is almost negligible from 1990s. The present analysis shows that the export of virtual water is much higher than the import of virtual water in result; India has become major water exporter from 1990 onwards. The volume of such net virtual water export can affect the overall sustainability of a nation like India in which per capita water availability is less than standard minimum water requirement. Therefore, the net virtual export of water through export of food grains and all crops can lead to loss of water sustainability in irreversible manner.

Thus, virtual water export in this trend may affect the overall water sustainability of India. Thus, there is need of water balance in virtual water trade of water scarce country like India. While dependency on blue water for rice production have accelerated to over extraction of ground water in India resulted ground water scarcity. Therefore, there is need to take policy decision for balancing the virtual water trade through reduction of virtual water export and promote to import virtual water through imports of high water demand agricultural products. Here, we have clear indications of significant impacts of virtual water export on water sustainability. Inclusion of other crops may affect the water sustainability.

\section{ACKNOWLEDGMENT}

We are thankful to Prof. Ranjana Aggarwal, Director, CSIR- National Institute of Science Communication and Policy Research for the support and encouragement.

\section{REFERENCES}

[1] M. Fallenmark, "Growing water scarcity in agriculture: future challenge to global water security", Philos. Trans. Roy. Soc. A, vol. 371, pp. 1-14, 2013.

[2] N.T. Graham, M. Hejazi, et al., "Humans drive future water scarcity changes across all Shared Socioeconomic Pathways," Environ. Res. Lett., vol. 15, 014007, 2020.

[3] M. Kummu, J.H.A. Guillaume et al., "The world's road to water scarcity: shortage and stress in the 20th century and pathways towards sustainability," Sci. Rep., vol. 6, 38495, 2016.

[4] L. Rosa et al. "Global agricultural economic water scarcity", Science Advances, vol. 26(18), eaaz6031, 2020.

[5] P. Goswami and S.N. Nishad, "Quantification of regional and global Sustainability based on combined resource criticality of land and water", Current Science, vol. 114(2), pp. 355-366, 2018.

[6] D. Grey, D. Garrick, D. Blackmore, et al., "Water security in one blue planet: twenty-first century policy challenges for science", Phil. Trans. R. Soc. A, vol. 371, pp. 20120406, 2013.

[7] E.M.K. Haacker, A.D. Kendall, D.W. Hyndman, "Water level declines in the high plains aquifer: Predevelopment to resource senescence", Groundwater, 54, 231-242, 2016.

[8] M.M. Mekonnen., A.Y. Hoekstra, "Four billion people facing severe water scarcity", Science Adv, vol. 2, e1500323, 2016.

[9] T. Oki., R.E. Quiocho, "Economically challenged and water scarce: identification of global populations most vulnerable to water crises" International Journal of Water Resources Development, vol. 36, pp. 416-428, 2020.

[10] D. Tilman, \& M. Clark, "Global diets link environmental sustainability and human health", Nature, vol. 515(7528), pp. 518-522, 2014.

[11] Liu and Savnije, "Food consumption patterns and their effect on water requirement in China", Hydrol. Earth Syst. Sci., vol. 12, pp. 887-898, 2008.

[12] J. Liu., A.J.B. Zehnder, and H. Yang, "Global consumptive water use for crop production: The importance of green water and virtual water", Water Resour. Res., vol. 45, W05428, 2009.

[13] P. Goswami and S.N. Nishad, Ensuring Self-sufficiency and Sustainability in the Agrofood Sector, In Sustainability Challenges in the agro-food sector, R. Bhatt, John Wiley \& Sons Ltd, 2017, Chapter 14.

[14] M.A. Qureshi, M.A. Hanjra, "Global water crisis and future security in an era of climate change", Food Policy, vol. 35(5), pp. 365-377, 2010.

[15] R.M. Saleth "Water scarcity and climatic change in India: the need for water demand and supply management", Hydrological Sciences Journal, vol .56, pp. 671-686, 2010.

[16] J.S.I Ingram and M. Brklacich, "Climate change and food security", Phil. Trans. R. Soc. B, vol. 360, pp. 2139-2148, 2005.

[17] N. Mancosu, R.L. Snyder, et al., "Water Scarcity and Future Challenges for Food Production", Water, vol. 7(3), pp. 975-992, 2015.

[18] P. Goswami and S.N. Nishad, "Virtual water trade and time scales for loss of water sustainability: A comparative regional analysis", Sci. Rep., vol. 5, 9306, 2015.

[19] S.K Sun., Y.L. Yin, P.T. Wu et al., "Geographical Evolution of Agricultural Production in China and Its Effects on Water Stress, Economy, and the Environment: The Virtual Water Perspective", Water Resource Research, vol. 55(5), pp. 4014-4029, 2019.

[20] J.A. Allan, "Virtual water: a strategic resource. Global solutions to regional deficits", Groundwater, vol. 36(4), pp. 545-546, 1998.

[21] T. Allan, "Virtual water: Tackling the threat to our planet's most precious resource", London: I.B. Tauris \& Co Ltd, 2011.

[22] A.K. Chapagain, A.Y. Hoekstra, HHG Savenije, "Saving water through global trade", Value of Water Research Report Series No. 17, UNESCO-IHE, Delft, the Netherlands, 2005.

[23] A.K. Chapagain, A.Y. Hoekstra, HHG Savenije, "Water saving through international trade of agricultural products", Hydrol Earth Syst Sci, vol. 10, pp. 455-468, 2006.

[24] R. Chittaranjan, D. McInnes, M. Sanderson, "Virtual water it's application on agriculture and trade", Water International, vol. 43, pp. 717-730, 2018.

[25] C. Dalin., M. Konar, N. Hanasaki, A. Rinaldo, I. Rodriguez-Iturbe, "Evolution of the global virtual water trade network", Proc. Nat. Acad. Sci., vol .109, pp. 5989-5994, 2012.

[26] A.E. Sadek, "Virtual water: an effective mechanism for integrated water resource management", Agricultural Sciences, vol. 2, pp. 248$261,2011$.

[27] T. Oki, S. Kanae, "Virtual Water trade and world water resources", Water Science and Technology, vol. 49 (7), pp. 203-209, 2004.

[28] C. Dalin, M. Konar, N. Hanasaki, A. Rinaldo and R. Iturbe R., "Water for food: The global virtual water trade network", Water Resources Research, vol. 47 (5), 2011.

[29] Z.M. Chen, G.Q. Chen, "Virtual water accounting for the globalized world economy: national water footprint and international virtual water trade", Ecological indicators, vol. 28, pp. 142-149, 2013.

[30] A.K. Chapagain, A.Y. Hoekstra, "The global component of freshwater demand and supply: an assessment of virtual water flows between nations as a result of trade in agricultural and industrial products", Water International, vol. 33(1), pp. 19-32, 2008.

[31] A.Y. Hoekstra, and P.Q. Hung, "Virtual water trade: a quantification of virtual water flows between nations in relation to international crop trade", Value of Water Research Report Series No.11, IHE, the Netherlands, 2002.

[32] A.Y. Hoekstra, P.Q. Hung, "Globalization of water resources: International virtual water flows in relation to crop trade", Global Environmental Change, vol. 15(1), pp. 45-56, 2005.

[33] M. Konar M., C. Dalin, S. Suweis, N. Hanasaki, et al., "Water for food: The global virtual water trade network", Water Resour. Res., vol. 47, W05520, 2011.

[34] D. Guan, K. Hubacek, "Assessment of regional trade and virtual water flows in China", Ecological economics, vol. 61 (1), pp. 159-170, 2007.

[35] S. Suweis, M. Konar, C. Dalin, N. Hanasaki, A. Rinaldo, IR Iturbe, "Structure and control of the global virtual water trade network", Geophysical Research Letters, vol. 38 (10), L10403, 2011.

[36] DA. Seekell, P. D'odorico, M.L. Pace, "Virtual Water transfers unlikely to redress inequality in global water use", Environmental Research Letters vol. 6 (2), pp. 024017, 2011.

[37] D. Wichelns, "The role of virtual water in efforts to achieve food security and other national goals, with an example from Egypt", Agricultural Water Management, vol. 49, pp. 131-151, 2001.

[38] H. Yang, A.J.B. Zehnder, "Virtual water: An unfolding concept in integrated water resources management", Water Resource Research, vol. 43(12), W12301, 2007.

[39] X. Zhao, Y.P. Li , H. Yang, W.F. Liu, M.R. Tillotson, D. Guan, Y. Yi, H. Wang, "Measuring scarce water saving from interregional virtual water flows in China", Environmental Research Letters, vol. 13 (5), $054012,2018$.

[40] H. Yang, L. Wang, K.C. Abbaspour, A.J.B Zehnder, "Virtual water trade: an assessment of water use efficiency in the international food 
trade", Hydrology and Earth System Sciences, vol. 10, pp. 443-454, 2006.

[41] D. Wichelns, "Virtual Water and water footprints offer limited insight regarding important policy questions", International journal of Water Resources Development, vol. 26, pp. 639-651, 2010.

[42] M. Lenzen, D. Moran, A. Bhaduri, K. Kanemoto, M. Bekchanov et al "International trade of scarce water", Ecological Economics, vol. 94, pp. 78-85, 2013.

[43] D. Wichelns, "Virtual Water: A Helpful Perspective, but not a Sufficient Policy Criterion", Water Resource management, vol. 24, pp. 2203-2219, 2010.

[44] A.K. Chapagain, A.Y. Hoekstra, "Water footprints of nations", Value of Water Research Report Series No. 16, UNESCO-IHE, Delft, The Netherlands. 2004.

[45] A.Y. Hoekstra, \& M.M. Mekonnen, "The water footprint of humanity", Proc. Nat. Acad. Sci., vol. 109 (9), pp. 3232-3237, 2012.

[46] M.M. Mekonnen, and A.Y. Hoekstra, "The green, blue and grey water footprint of crops and derived crop products", Value of Water Research Report Series No. 47, UNESCO-IHE, Delft, the Netherlands, 2010.

[47] S. Mohammed, M. Darwish, "Water footprint and virtual water trade in Qatar", Desalination and Water Treatment, vol. 66, pp. 117-132, 2017.

[48] Composite Water Management Index report June 2018 NITI Aayog FAOSTAT Division http://faostat.fao.org/AQUASTAT, FAO Rome.Water Information. Central Water Commission, Ministry of Jal Shakti, Govt. of India.

[49] M.D. Kumar, O.P. Singh, "Virtual Water in Global Food and Water Policy Making: Is There a Need for Rethinking?", Water Resources Management, 19, 759-789, 2005. 